\title{
Manajemen Pendidikan dan Pelatihan Satpam untuk Meningkatkan Mutu Lulusan
}

Eka Kurniawan' ${ }^{1}$, Ade Tutty R Rosa ${ }^{2}$, Sri Handayani ${ }^{3}$

1,2,3Sekolah Pascasarjana, Universitas Islam Nusantara Bandung, Indonesia

E-mail: ekagemaputra@gmail.com

\begin{tabular}{|c|c|}
\hline Article Info & Abstract \\
\hline $\begin{array}{l}\text { Article History } \\
\text { Received: } 2021-11-20 \\
\text { Revised: } 2021-12-15 \\
\text { Published: 2022-01-03 }\end{array}$ & $\begin{array}{l}\text { The type of research used in this study is qualitative with a descriptive approach } \\
\text { (subject perspective). Management of Education and Training of security forces in } \\
\text { improving the quality of graduates at PT Hazimah Pradhana Sakti and PT Prima } \\
\text { Handanu Bhakti are the two companies in collaboration with the POLDA and the local } \\
\text { Polres and have good relations. Planning begins with curriculum development, } \\
\text { financial planning, preparation for student admissions, facilities and infrastructure and } \\
\text { good relations with work partners. In the implementation of reviewing and analyzing } \\
\text { the implementation of the education and training of security forces to improve the } \\
\text { quality of graduates at PT Hazimah Pradhana Sakti and PT Prima Handanu Bhakti, the } \\
\text { implementation of each element of education was in accordance with what was } \\
\text { previously planned. Looking for solutions to problems faced in the education and } \\
\text { training process of security forces to improve the quality of graduates at PT Hazimah } \\
\text { Pradhana Sakti and PT Prima Handanu Bhakti? Based on efforts to deal with the } \\
\text { problems faced in education, training is carried out as early as possible in making } \\
\text { decisions between the field and the head office, minimizing the emergence of problems } \\
\text { so that in carrying out education training runs smoothly. }\end{array}$ \\
\hline
\end{tabular}

\begin{tabular}{l} 
Artikel Info \\
\hline Sejarah Artikel \\
Diterima: 2021-11-20 \\
Direvisi: 2021-12-15 \\
Dipublikasi: 2022-01-03 \\
\\
Kata kunci: \\
Manajemen Pendidikan; \\
Pelatihan; \\
Satpam.
\end{tabular}

Abstrak

Jenis penelitian yang digunakan dalam penelitian ini adalah Kualitatif dengan pendekatan Deskriptif (perspektif subjek). Manajemen Pendidikan dan Pelatihan satuan pengamanan dalam meningkatkan mutu lulusan di PT Hazimah Pradhana Sakti dan PT Prima Handanu Bhakti adalah kedua perusahaan tersebut berkolaboarsi dengan POLDA dan Polres setempat dan behubungan dengan baik. Perencanaan diawali dengan pembuatan kurikulum, perencanaan keuangan, persiapan penerimaan peserta didik, sarana dan prasarana dan berhubungan baik dengan mitra kerja. Dalam pelaksanaan mengkaji dan menganalisis pelaksanaan dalam Pendidikan dan Pelatihan satuan pengamanan untuk meningkatkan mutu lulusan di PT Hazimah Pradhana Sakti dan PT Prima Handanu Bhakti, pelaksanaan setiap unsur pendidikan sudah sesuai dengan yang direncanakan sebelumnya. Dalam Mencari Solusi dari untuk masalah yang dihadapi dalam proses Pendidikan dan Pelatihan satuan pengamanan untuk meningkatkan mutu lulusan di PT Hazimah Pradhana Sakti dan PT Prima Handanu Bhakti? Berdasarkan upaya menghadapi masalah yang dihadapi dala pendidikan pelatihan melakukan koordinasi sedini mungkin dalam mengambil keputusan antara pihak lapangan dan kantor pusat, meminimalisir muncunya masalah sehingga dalam melaksanakan pendidikan pelatihan berjaan dengan lancar.

\section{PENDAHULUAN}

Keamanan merupakan kebutuhan dasar manusia, status seseorang dalam keadaan aman yaitu terlindunginya kondisi fisik, sosial, spiritual, finansial, politik, emosi pekerjaan, psikologis atau berbagai akibat dari sebuah kegagalan, kerusakan dan kecelakaan. Kebutuhan dasar manusia merupakan unsur-unsur yang dibutuhkan manusia dalam menjaga keseimbangan baik secara fisiologis maupun psikologis yang mempunyai tujuan untuk mempertahankan kehidupan dan kesehatannya, permasalahan selama ini banyak Satpam yang belum mendapatkan pendidikan dan pelatihan dasar Satpam dengan kualifikasi Gada Pratama dan ada juga yang melakukan perekrutan dilakukan oleh TNI, sehingga sertifikatnya TNI tidak bisa menerbitkan. Perekrutan tenaga kerja Satpam yang dilakukan Instansi / perusahaan hanya melihat tenaga kerja lokal yang belum diberikan pendidikan dan pelatihan.

Berdasarkan Undang-Undang No. 20 Tahun 2003 tentang Sistem Pendidikan Nasional, Pasal 13 ayat (1) memaparkan bahwa "Jalur Pendidikan terdiri atas pendidikan formal, nonformal, dan informal yang dapat saling melengkapi dan memperkaya". Sumber daya manusia yang unggul tentunya tidak hanya unggul dibidang 
akademik saja namun juga harus memiliki keterampilan yang dapat dijadikan sebagai keunggulan dalam dirinya. Pendidikan Luar Sekolah merupakan salah satu jalur pendidikan yang masuk dalam jalur pendidikan nonformal. Pendidikan dan pelatihan merupakan proses yang disengaja atau direncanakan, bukan kegiatan yang bersifat kebetulan atau spontan serta termasuk dari bagian pendidikan yang menyangkut proses belajar yang dilaksanakan di luar sistem sekolah, memerlukan waktu yang relatif singkat, dan lebih menekankan praktik (Mustofa,2010:10).

Lembaga Pendidikan dan pelatihan satpam memiliki andil yang sangat penting untuk mencetak calon Tenaga pengaman yang professional dan memiliki keterampilan dalam bidang pengamanan. Oleh karenanya lembaga pendidikan dan pelatihan SATPAM sangat dibutuhkan di era sekarang ini. Peranan Satuan Pengamanan (Security sangat membantu terciptanya situasi dan lingkungan yang aman, nyaman dan tentram serta tertib). Satpam resmi, selain mendapatkan sertifikat dari Polri sebagai pengemban fungsi kepolisian terbatas tugasnya pun semakin penting yakni sebagai garda terdepan untuk pengamanan terutama pada perusahaan atau instansi. Melalui diklat satuan pengamanan (SATPAM), diharapkan lahirnya satpam yang mempunyai kompetensi yang lebih maksimal dalam menjalankan tugasnya di antara Masyarakat, tetapi kenyataan dilapangan tidak sesuai dengan kenyataan, kurangnya kompetensi satpam yang dimiliki menjadi salah satu penyebab kurang terlaksananya Kamtibmas.

Dalam rangka memelihara dan meningkatkan kondisi keamanan dan ketertiban masyarakat agar mampu melindungi seluruh warga masyarakat Indonesia pada pelaksanaan kegiatan seharihari, meningkatkan kualitas hidup yang bebas dari ancaman, gangguan, hambatan yang dapat menimbulkan kerugian harta benda dan jiwa dan raga yang pada terganggunya kondusifitas situasi kamtibmas sehingga menghambat terselenggaranya pembangunan Nasional dalam mewujudkan kesejahteraan, kebijakan tahun 2017 adalah membangun Polri sebagai inti kekuatan dalam penyelenggaraan keamanan didukung komponen masyarakat dan Negara dalam membudayakan tata hukum untuk menegakan supremasi hukum.

Ditmas sebagai salah satu fungsi Kepolisian di tingkat Polda memiliki peranan untuk melakukan pembinaan dan pendekatan kepada masyarakat dalam rangka menciptakan situasi dan kondisi yang aman dan tentram serta dapat memberikan lahan dan atau peluang pekerjaan bagi masyarakat itu sendiri. Hal tersebut mendorong untuk ditingkatkannya kualitas dari sebuah lembaga pelatihan khususnya pelatihan satpam guna meningkatkan hasil mutu lulusan dan dapat menambah rasa aman dalam masyarakat. Peneliti memilih PT Hazimah Pradhana Sakti dan PT Prima Handanu Bhakti sebagai tempat penelitian karena dari beberapa lembaga pendidikan dan pelatihan, kedua lembaga tersebut dinilai mempunyai kelebihan tersendiri dalam proses pelaksanaan, penilaian, pengorganisasian sampai disalurkannya ke perusahan-perusahan yang sudah bekerja sama dengan lembaga tersebut. Jika dilihat dari kualitas satpam yang telah menyelesaikan Pendidikan dan pelatihannya di kedua lembaga tersebut, ada perbedaan dengan satpam yang berasal dari lembaga pelatihan yang lain, dapat dilihat dari profesionalisme, tanggung jawab, dan dapat di mengupdate diri nya sendiri sesuai dengan perkembangan zaman dan tentunya adanya tuntutan, arahan dari kepolisian dan perusahaan tempat dia bernaung.

Berdasarkan latar belakang yang telah diuraikan diatas, dan ditindaklanjuti hasil-hasil penelitian terdahulu, maka peneliti dapat mengambil judul "Manajemen Pendidikan dan Pelatihan satuan pengamanan untuk meningkatkan mutu lulusan" (Penelitian di PT Prima Handanu Bhakti dan PT Hazimah Pradhana Sakti).

\section{METODE PENELITIAN}

Metode penelitian ini yaitu menggunakan pendekatan kualititatif dengan penelitian deskriptif. Dapat dikatakan bahwa penelitian deskriptif merupakan penelitian yang berusaha mendeskripsikan suatu gejala, peristiwa yang terjadi pada saat sekarang atau masalah aktual. Teknik pengumpulan data dalam penelitian ini menggunakan teknik pengumpulan data wawancara, observasi terlibat dan angket. Teknik pengolahan data yang digunakan dalam penelitian ini adalah analisis data kualitiatif yang dilakukan secara interaktif dan berlangsung secara terus menerus sampai tuntas, sehingga datanya sudah jenuh Teknik analisis data yang digunakan dalam penelitian kualitatif mencakup transkip hasil wawancara, reduksi data, analisis, interpretasi data dan triangulasi. Lokasi penelitian adalah di 2 tempat yakni di PT. Hazimah Pradhana Sakti dan PT. Prima Handanu Bhakti. PT Hazimah Pradhana Sakti bertempat di Gedung Griya Krida Sekesalam, RT. 01 RW. 08 Desa Sindanglaya Kecamatan Cimeyan Bandung Jawa Barat dan Pusat Pendidikan dan Pelatihan Satpam PRIMA 
yang terletak dikaki gunung Manglayang Cileunyi, Bandung.

\section{HASIL DAN PEMBAHASAN}

\section{A. Hasil Penelitian}

1. Implementasi Program pendidikan dan Pelatihan SATPAM PT Hazimah Pradhana Sakti

Pengembangan kurikulum dibuat sebelum pelaksanaan pelatihan berlangsung dengan persiapan yang matang sehingga terlaksana kegiatan pelatihan sesuai tujuan perusahaan. Setelah dilakukan pengembangan dilanjutkan dengan evaluasi kurikulum agar pendidikan pelatihan di PT Hazimah Pradhana Sakti dapat terus berjalan dengan baik dan lebih baik lagi. Inti dari kurikulum tersebutdapat dismpulkan yaitu, perencanaan pembelajaran dan pelaksanaan pelatihan Satuan Pengamanan atau SATPAM, bertujuan agar menjadikan satpam yang professional dalam berbagai bidang.

Tugas Pendidik dan Tenaga Kependidikan melakukan persiapan dalam hal pelatihan yang mencakup dalam pelatihan dasar, pelatihan lanjutan, dan pelatihan utama dalam hal keamnan serta menentukan bagaimana metode pelatihan yang akan diterapkan baik dalam pelatihan fisik dan mental serta tidak lupa mempersiapkan desain materi yang akan di sampaikan nanti pada bidang pengetahuan peserta didik. Pendidikan dan latihan untuk membentuk kepribadian secara utuh artinya bahwa pembinaan bukan hanya berorientasi pada aspek fisik saja, tetapi juga dimaksudkan untuk membina mental spiritual. Selain itu juga pendidikan dan latihan juga dapat meningkatkan pengetahuan, kemampuan, keterampilan baik teknis maupun administratif serta dapat membentuk keseragaman pola pikir guna mencapai keberhasilan tugas-tugas pemerintah dan pembangunan sehingga dapat dijadikan panutan sebagai manusia yang hidup di masyarakat.

Perencanaan tentulah ada yang bertugas dan melakukan perencanaan dana atau membuat RAB untuk keberlang-sungan program pendidikan pelatihan, pembuatan RAB mencangkup perencanaan anggran, strategi pengunaan anggaran pengunaan anggran pengawasan. Sumber keuangan didapatkan dari pihak kerja sama dan dari peserta didik. Bagian RAB. sarana dan prasarana di PT sudah memadai. Mulai dari tempat diklat yang baik, sarana prasarana yang menunjang dalam melaksanakan pendidikan pelatihan, fasilitias barak, ruangan untuk peserta didik melakukan pelatihan.

Lulusan yang diharapkan oleh PT Hazimah Pradana Sakti yaitu, memiliki keterampilan berfikir semakin baik dan memiliki keterampilan dalam berfikir. Lulusan PT Hazimah Pradhana Sakti dapat mempraktekan salah satu mata pelajaran IPS (Ilmu Pengetahuan Sosial). Tidak hanya itu, dalam aspek sikap peseta didik diharapkan memiliki sikap yang mana dapat mengukur seperti apa sikap mereka saat bertugas. Keterampilan motorik peserta didik pelatihan diharapkan memiliki keterampilan motorik yang baik dimana memiliki kesigapan yang baik dan kemampuan bela diri yang mumpuni. Prestasi yang dimiliki oleh PT Hazimah Pradana Sakti yaitu, sudahbanyak melatih anggota security yang handal diberbagai instansi, dipercayai oleh perusahaan yang terkemuka yang berkualitas. Harapan PT. Hazimah Pradhana Sakti harus bisa lebih maju dan mampu melayani jasa keamanan yang tentunya sudah terpercaya oleh berbagai pihak dan sesuai tujuan kami untuk melakukan pelatihan keprofesian dalam bidang keamanan kami akan senantiasa berusaha untuk melaksanakannya dengan sebaik mungkin dan terpercaya baik dari segi keprofesionalanya dan sebagainya.

Dalam pelaksanaan program Manajemen pendidikan pelatihan terkadag tidak sesuai dengan apa yang direncanakan, terkadang ada beberapa hambatan-hambatan yang harus di selesaikan. Seperti komunikasi, koordinasi atau salah paham yang sering kali menjadi hambatan dalam pelaksanaan pendidikan pelatihan. Namun Terselenggaranya pelaksanaan manajemen pendidikan pelatihan karena adanya dukungan dari berbagai pihak, baik dari pegawai, pengelola, pembina dan administrasi serta instruktur dalam menjalankan pendidikan pelatihan

Hazimah Guard merupakan pengelolaan keamanan serta penyediaan personil. Melalui seleksi berdasarkan kriteria yang sudah ditentukan dan ditempatkan sesuai 
standarisasi keamanan di lokasi penjagaan. Distribusi Satuan Pengamanan dan jadwal kerja di sesuaikan dengan area penjagaan dan kebutuhan klien. Supervisor Area tanggung jawab atas keamanan di seluruh area penjagaan, serta sebagai kordinator dengan kepolisian setempat saat dibutuhkan. Keluaran peserta didik setelah mengikuti proses pendidikan di PT Prima Handanu Bhakti peserta didik mampu berpikir kritis dan memiliki pengetahuan yang luas sehingga dalam melakukan tugas keamanan peserta didik memiliki landasan dalam melakukan tugasnya.

2. Implementasi Program pendidikan dan Pelatihan SATPAM di PT Prima Handanu Bakti

Kurikulum dibuat dengan tim dosen ahli, pelatih, manajer dan saling mengkoordinasi dengan pihak tenaga profesional. Pelaksanaan kurikulum dilaksanakan pada saat awal pelatihan samapi akhir. Isi dari kurikulum tersebut berkenaan dengan bidang keamanan seperti pembinaan mental, pendidikan dan pelatihan fisik, pengembangan motivasi, peningkatan keterampilan dan pendidikan teori teknik yang mendukung saat tugas nanti, aspek pendidik dan tenaga kependidikan yaitu, ada beebrapa hal yang harus di persiapkan rekrutmen tenaga pendidik dan tenaga kependidikan adalah tentunya kemampuan dan keterampilan dalam melaksanakn kegiatan pelatihan, baik itu pelatihan dasar sampai dengan pelatihan utama serta mempersiapkan juga design serta motede pelatihan dan pembelajaran. Yang melakukan proses rekrutmen pendidik dan tenaga pendidik adalah pihak-pihak yang bersangkutan salah satunya dari tim penanggung jawab setiap kegiatan yang dilakukan baik dalam pelaksanaan pelatihan dan pendidikan. eserta didik merupakan aspek terpenting dalam melaksanakan Pendidikan pelatihan. Karena jika tidak ada peserta didik pendidikan pelatihan tidak akan bisa berjalan.

Dalam mengelola keuangan di PT. Handanu Bhakti yaitu manajer keuangan. Manajer keuangan bertugas mempersiapkan perencanan anggara serta mencatat setiap uang yang masuk dan keluar. Sumber daba yang di dapatkan dari pendaftaran peserta didik dan perusahaan yang berkeja sama dengan PT. Prima Handanu Bhakti. , sarana dan prasarana di PT. Prima Handanu memiliki fasiltitas yang sangat lengkap. Jika ada sarana dan prasarana yang tidak layak pihak petugas operasional akan merenovasi atau pengganti yang baru agar proses pelatihan dan pendidikan dapat dilakukan secara baik dan nyaman.

PT Prima Handanu Bhakti dalam menyalurkan lulusan dan meningkatkan mutu lulusan ialah, perusahaan berusaha agar lulusan dapat bekerja di perusahaan besar. PT. Prima Handanu Bhakti bekerja sama dengan beberapa mitra kerja sehingga lulusan dari PT. Prima Handanu Bhakti dapat bekerja di beberapa mitra kerja. PT. Prima Handanu Bhakti memiliki berbagai cara dalam meningkatkan mutu lulusan sehingga para lulusan dapat mendapatkan pekerjaan dengan cepat dan berprestasi.

Faktor penghambat merupakan hal yang memiliki sifat menghambat atau bahkan menghalangi dan menahan terjadinya sesuatu. Setiap perusahaan tetunya akan menemukan faktor penghambat dalam menjalankan tugas. Walaupun terdapat faktor penghambat, sebaiknya seorang pemimpin dapat meminimalisir dan menyikapi faktor penghambat tersebut. Faktor pendukung di PT. Prima Handanu Bhakti memiliki beberapa pendukung dalam melaksanan pendidikan pelatihan seperti, tenaga pendidik yang berpengalaman dalam bidangnya, fasilitas yang sangat lengkap dan memadai dan tentunya masih banyak lagi faktor pendukung yang mendukung terlaksananya pendidikan pelatihan.

Setiap perusahaan tentunya memiki harapan yang besar terhadap lulusannya dan memiki prestasi setelah mengikuti pendidikan pelatihan. Menurut bapak PAN selaku C.B.D.O memaparkan bahwa PT. Prima Handanu Bhakti memiliki harapan dan prestasi yang diraih oleh lulusan atau yang sering disebut alumni, yaitu "Harapan kami adalah dapat mewujudkan security yang dapat menimbulkan rasa keamanan dan kenyamanan bagi masyarakat dan perusahaan yang bekerja sama dengan kami. Prestasi yang kami dapatkan adalah tentunya kami sudah melatih satpam Gada Pratama 457 angkatan dengan sebanyak 22.140 orang dan Gada Madya 72 angkatan dengan 922 orang serta ratusan perusah- 
aan yang telah mempercayakan satpam yang telah kami latih." Dari pernyataan diatas dapat disimpulkan bahwa, harapan terbesar yang diinginkan oleh PT. Prima Handanu Bhakti yaitudapat mewujudkan SATPAM yang dapat dan memberikan keamanan dan kenyamanan bagi masyarakat serta selalu memberikan prestasiprestasi terbaik dari lulusan terbaik.

Dalam penelitian ini peneliti menemukan beberapa temuan. Berikut adalah penjelasan hasil penelitian yang telah dilakukan yaitu:

a) Perencanaan dalam melaksanakan pendidikan pelatihan satuan pengamanan.

b) Dari data penelitian, penelitian menggunakan teknik wawancara, angket dan observasi untuk mengumpulkan dta. Data yang diperoleh akan dipilih dan dipilah yang akan dianalisis. Dalam pelaksanaan kegiatan pendidikan pelatihan SATPAM dikatakan perusahaan tersebut mempunyai rencana (planinning) yang dilakukan secara sistematis. Terry dalam Surapto (2000 : 12) mendefinisikan management merupakan sebuah proses yang khas, yang terdiri dari tindakan-tindakan: perencanaan, pengorganisasian, penggiatan, dan pengawasan yang dilakukan untuk menentukan serta mencapai sasaransasaran yang telah ditetapkan melalui pemanfaatan sumber daya manusia dan sumber- sumber lainnya. Berdasarkan hasil penelitian tersebut, peran Perusahaan dan Instruktur paling banyak berkaitan dengan pembelajaran pendidikan pelatihan. Hal ini menujukan bahwa: Perusahaan sangat berperan dalam peningkatan mutu pendidikan dan mutu Lulusan. Perusahaan dan Instruktur juga harus paham tentang pembelajaran, mulai dari merencanakan, melaksanakan, sampai pada evaluasi sebagai bahan pembinaan instruktur dalam menngkatkan kinerjanya.

Sebagai perusahaan, pemimpin sebaiknya melakukan tugas sebagai manajer pendidikan menurut Wuradji (2008) adalah:

a) Menyusun perencanaan secara matang tentang tujuan dan strategi pencapaian tujuan b) Melakukan pengorganisasian potensi sumber-sumber Pendidikan yang ada

c) Melaksanakan kegiatan.

d) Mengadakan control secara rutin terhadap pelaksanaan dan hasil pendidikan.

Dengan menerapkan Manajemen pelatihan Pendidikan dianggap telah meningkatkan mutu lulusan satuan pengamanan. Dalam hal tersebut dibuktikan dengan hasil wawancara dan angket yang diberilan dalam pembelajaran pendidikan pelatihan. Manajemen Pelatihan dan Pendidikan satuan pengamanan dapat meningkatkan mutu lulusan.

\section{B. Pembahasan}

1. Mendeskripsikan dan Menganalisis Proses perencanaan dalam manajemen Pendidikan dan Pelatihan satuan pengamanan untuk meningkatkan mutu lulusan di PT Prima Handanu Bhakti dan PT Hazimah Pradhana Sakti

Kurikulum yang digunakan dalam menyelenggarakan pendidikan pelatihan yaitu merujuk kepada Kurikulum Polda Jabar. Menurut Notoatmodjo (2011:56) yang menyatakan bahwa ada beberapa tahapan dalam perencanaan salah satunya melakukan pengembangan kurikulum yaitu : Dari tujuan-tujuan diklat yang telah dirumuskan tadi akan dapat diketahui kemampuan-kemampuan apa yang harus diberikan dalam pelatihan. Maka selanjutnya di identifikasi materi-materi atau bahan-bahan pelajaran yang akan diberikan pelatihan. Dengan kata lain materi-materi apa yang dapat mengembangkan atau meningkatkan kemampuan para peserta diklat. Selanjutnya dilakukan identifikasi waktu yang diperlukan untuk tiap-tiap materi atau topic/sub topic yang lebih ternci. Setelah itu di tentukan metoda beljar mengajar yang diperlukan dalam pelatihan tersebut. Proses ini disebut pengembangan kurikulum (curriculum development).

Pernyataan diatas senada dengan yang dilakukan oleh PT Hazimah Pradhana Sakti dan PT. Pima Handanu Bhakti, dalam menciptakan tenaga pengamanan yang berkompeten dalam bidang Security atau Satuan Pengamanan. Sebelum melaksanakan pendidikan dan pelatihan diklat 
adalah melakukan perencanaan program pendidikan terlebih dahulu.

Dalam melakukan perencanaan terdapat persiapan-persiapan yang harus dilakukan untuk mulai melakukan kegiatan seperti rapat rutin, melakukan penawaran kerjasama di perusahaan-perusahaan atau instansi. Tidak hanya itu, persiapan yang dilakukan sebelum pelaksanan adalah koordinasi dengan POLDA dan Polres setempat, agar pelaksanaan berjalan dengan lancar. Selain itu perumusan dan persiapan kurikulum supaya pendidikan pelatihan berjalan dengan lancar dan memberikan pembelajaran yang maksimal.

Selain itu perencanaan keuangan sangat penting dalam melakukan kegiatan pendidikan pelatihan. Dimulai dri pembuatan RAB, yang dilakukan oleh bagian keuangan, tahap selanjutnya mengajukan kepada kepala divisi keuangan, apabila telah disetujui akan direalisasikan untuk keberlangsungan diklat. PT Hazimah Pradhana Sakti dan PT Prima Handanu Bhakti memiliki kesamaan dalam persiapan keuangan, yaitu selau menyiapkan RAB untuk keberlangsungan program pendidikan pelatihan dan melakukan strategi penggunaan anggaran.

2. Melaksanakan Pendidikan dan Pelatihan satuan pengamanan untuk meningkatkan mutu lulusan di PT Prima Handanu Bhakti dan PT Hazimah Pradhana Sakti

Pendikan dan pelatihan merupakan upaya yan dilakukan oleh manusia dalam menamnah pengetahuan dan keterampilan yang sesuai dengan diinginkan. Profesi sabagai satuan pengamanan merupakan salah satu tujuan yang ingin dicapai oleh peserta pelatihan serta mengikuti pendidikan dan pelatihan. Peserta didik selama mengikuti penddikan dan pelatihan sudah dibekali dengan pengetahuan-pengetahuan sehingga memiliki skill dalam menerapkan fungsi dan peranan SATPAM. Upaya yang dilakukan PT. Hazimah Pradhana Sakti dan PT Prima Handanu Bhakti yaitu, selalu memberikan materi pembelajaran yang terbaik bagi peserta didik dan mampu menguasai interpersonal skill, etika profesi, tugas pokok, fungsi dan peranan SATPAM serta kemampuan kepolisian terbatas, seperti kegiatan bela diri, menembak, pengenalan bahan peledak, pengetahuan narkotika dan zat adiktif lainya serta penggunaan tongkat dan borgol.

Mutu lulusan yang diharapkan dari kedua perusahaan tersebut adalah Terserapnya tenaga kerja di bidang jasa pengamanan dengan melibatkan putra daerah untuk ikut serta berperan dalam menjaga kamtibmas di daerahnya sehingga mengurangi angka pengangguran dan sekaligus meningkatkan kesejahteraan masyarakat; Terbentuknya satpam yang mempunyai kompetensi Gada Pratama (bersertifikasi) yang mampu menjalankan tugas pokok fungsi sebagai satpam yang profesional; Peran serta masyarakat dalam pengamanan swakarsa serta mewujudkan satpam yang mampu berperan sebagai pengemban fungsi kepolisian terbatas di tempat kerjanya dalam menjaga kamtibmas yang kondusif.

3. Mengevaluasi penilaian dalam Pendidikan dan Pelatihan satuan pengamanan untuk meningkatkan mutu lulusan di PT Prima Handanu Bhakti dan PT Hazimah Pradhana Sakti

Evaluasi yang dilakukan oleh PT. Hazimah Pradhana Sakti dan PT. Prima Handanu Bhakti terhadap perserta didik adalah evaluasi berupa mengetahui sejauh mana peserta didik menerima materi pembelajaran, seperti yang dipaparkan oleh Athur (Athur, 2018) evaluasi program diklat adalah : Evaluasi peserta meliputi pre/post test,ujian tertulis, ujian praktik, ujian komprehensif, evaluasi tatap muka, evaluasi pengajar, dan evaluasi penyelenggaraan Evaluasi pengajar meliputi penampilan pengajar meliputi penampilan pengajar, metode pembelajaran, kemampuan mengelola waktu dan sistematika penyampaian. Evaluasi penyelenggaraan terdiri dari kurikulum,pelayanan penyelenggara, ruang makan dan konsumsi, sarana dan prasarana.

PT Hazimah Pradhana Sakti dan PT Prima Handanu Bhakti melakukan evaluasi terhadap proses dengan cara melakukan penilaian harian, bulanan, dan melakukan tes tertulis dan praktek kepada peserta didik. Pemberian ijazah sebagai bukti bahwa peserta didik telah melaksanakan diklat dan mendapatkan hasil nilai atas kerja kerasnya dalam melaksanakan diklat. 
4. Mengkaji Masalah yang dihadapi dalam Pendidikan dan Pelatihan Satuan pengamanan untuk meningkatkan mutu lulusan di PT Prima Handanu Bhakti dan PT Hazimah Pradhana Sakti

a) Faktor Penghambat

Dapat disimpulkan dari kedua perusahaan tersebut, adanya faktor penghambat dalam pelaksanaan pendidikan diklat adalah, sering terjadinya salah paham antara pihak lapangan dan kantor, kurangnya komunikasi merupakan faktor penghambat. Kejadian dilapangan tidak dapat dipastian, muali dari cuaca, kedatangan instruktur dan keadaan pendidikan. Mungkin yang haris diperhatian oleh karyawan yang ada dikantor adalah selalu berkomunikasi dengan baik sehingga pihak kantor dan pihak lapangan miliki informasi yang sama.

b) Faktor Pendukung

Memiliki hubungan yang baik dengan karyawan satu sama lain akan mempengaruhi keberlangsungan pelaksanaan kegiatan pendidikan pelatihan, karena tanpa adanya hubungan yang baik, koordinasi tidak akan berjalan dengan lancar. Berdasarkan pengamatan dan observasi oleh peneliti, koordinasi dilakukan dengan baik. Hubungan yang baik antara karyawan akan memperlancar pekerjaan mulai dari administrasi, keuangan serta kerja di lapangan. Peserta didik merupakan salah satu faktor pendukung dalam pelaksanaan pendidikan dan pelatihan. Tanpa adanya peserta didik, pendidikan pelatihan tidak akan berjalan dengan lancar. Sarana dan Prasanana merupakan aspek terpenting yang tekadang diabaikan. Tanpa adanya Sarana dan Prasarana pendidikan pelatihan tidak akan berjalan dengan lancar. Berdasarkan hasil pengamatan peneliti mendapatkan kesimpulan setiap perusahaan memiliki persamaan dan kelebihan pada sarana dan prasarana. Mulai dari sarana yang digunakan untuk membelajaran, tempa tidur bagi peserta didik, fasilitas MCK serta sarana untuk melakukan praktekpraktek untuk mengembangkan skill peserta didik.
5. Mencari Solusi dari untuk masalah yang dihadapi dalam proses Pendidikan dan Pelatihan satuan pengamanan untuk meningkatkan mutu lulusan di PT Prima Handanu Bhakti dan PT Hazimah Pradhana Sakti

Pendikan dan pelatihan merupakan upaya yan dilakukan oleh manusia dalam menamnah pengetahuan dan keterampilan yang sesuai dengan diinginkan. Profesi sabagai satuan pengamanan merupakan salah satu tujuan yang ingin dicapai oleh peserta pelatihan serta mengikuti pendidikan dan pelatihan. Peserta didik selama mengikuti penddikan dan pelatihan sudah dibekali dengan pengetahuan-pengtahuan sehingga memiliki skill dalam menerapkan fungsi dan peranan SATPAM. Upaya yang dilakukan PT. Hazimah Pradhana Sakti dan PT Prima Handanu Bhakti yaitu, selalu memberikan materi pembelajaran yang terbaik bagi peserta didik dan mampu menguasai interpersonal skill, etika profesi, tugas pokok, fungsi dan peranan SATPAM serta kemampuan kepolisian terbatas, seperti kegiatan bela diri, menembak, pengenalan bahan peledak, pengetahuan narkotika dan zat adiktif lainya serta penggunaan tongkat dan borgol.

\section{SIMPULAN DAN SARAN}

\section{A. Simpulan}

Berdasarkan Peneltiian yang telah dilakukan, adapun kesimpulan sebagai berikut:

a. Berdasarkan Proses perencanaan dalam manajemen Pendidikan dan Pelatihan satuan pengamanan dalam meningkatkan mutu lulusan di PT Hazimah Pradhana Sakti dan PT Prima Handanu Bhakti adalah kedua perusahaan tersebut berkolaborasi dengan POLDA dan Polres setempat dan behubungan dengan baik. Perencanaan diawali dengan pembuatan kurikulum, perencanaan keuangan, persiapan penerimaan peserta didik, sarana dan prasarana dan berhubungan baik dengan mitra kerja.

b. Dalam pelaksanaan mengkaji dan menganalisis pelaksanaan dalam Pendidikan dan Pelatihan satuan pengamanan untuk meningkatkan mutu lulusan di PT Hazimah Pradhana Sakti dan PT Prima Handanu Bhakti, pelaksanaan setiap unsur pendidikan sudah sesuai dengan yang direncanakan sebelumnya. Sesuai dengan Peraturan 
Kepolisian Nomor 24 Tahun 2007 proses penyelenggaraan pendidikan dan pelatihan sudah sesuai dengan peraturan tersebut.

c. Bagaimana Mengevaluasi penilaian dalam Pendidikan dan Pelatihan satuan pengamanan untuk meningkatkan mutu lulusan di PT Hazimah Pradhana Sakti dan PT Prima Handanu Bhakti. Dalam melaksanakan evaluasi kedua perusahaan tersebut menggunakan beberapa aspek penilaian seperti melakukan evaluasi terhadap proses dengan cara melakukan penilaian harian, bulanan, dan melakukan tes tertulis dan praktek kepada peserta didik. Pemberian ijazah sebagai bukti bahwa Peserta didik telah melaksanakan diklat dan mendap-atkan hasil nilai atas kerja kerasnya dalam melaksanakan diklat.

d. Penanganan Masalah yang dihadapi dalam Pendidikan dan Pelatihan Satuan pengamanan untuk meningkatkan mutu lulusan di PT Hazimah Pradhana Sakti dan PT Prima Handanu Bhakti. Dalam menghadapi permasalahan tersebut, pimpinan selaku kedua perusahaan memiliki strategi dalam mengkaji masalah. Sedini mungkin menghindari masalah agar terhindar dari hambatan dalam meningkatkan mutu lulusan saat pelaksanaan pendidikan pelatihan.

e. Dalam Mencari Solusi dari untuk masalah yang dihadapi dalam proses Pendidikan dan Pelatihan satuan pengamanan untuk meningkatkan mutu lulusan di PT Hazimah Pradhana Sakti dan PT Prima Handanu Bhakti Berdasarkan upaya menghadapi masalah yang dihadapi dala pendidikan pelatihan melakukan koordinasi sedini mungkin dalam mengambil keputusan antara pihak lapangan dan kantor pusat, meminimalisir muncunya masalah sehingga dalam melaksanakan pendidikan pelatihan berjaan dengan lancar.

\section{B. Saran}

Adapun saran penelitian yang diberikan oleh peneliti, peneliti memiliki beberapa saran dalam melaksanakan penelitian yaitu, Penelitian ini dapat dilakukan kembali dan menganalisis kembali dalam meningkatkan mutu lulusan pelatihan pendidikan SATPAM. Menambahkan aspek disiplin kerja serta menambahkan dimensi atau indikator agar dapat menghasilkan suatu model struktural yang lebih kompleks dan menjawab lebih banyak pertanyaan-pertanyaan lainya.

\section{DAFTAR RUJUKAN}

Achmad Sanusi. 2013. Kepemimpinan Pendidikan: Strategi Pembaruan, Semangat Pengabdian, Manajemen Modern. Nuansa Cendekia: Bandung

Andesti, N. (2015). Pengaruh Pelatihan Terhadap Kinerja Satpam Ditinjau Menurut Ekonomi Islam (Studi Kasus Pada Pt. Bravo Satria Perkasa Pekanbaru) (Doctoral Dissertation, Universitas Islam Negeri Sultan Syarif Kasim Riau).Angkutan Jalan, Departemen Perhubungan, Jakarta.

Bernardin, H.John And Russel. 2010. Human Resource Management. New York: Mcgraw-Hill

Depdiknas .2003. Undang-Undang Ri No.20 Tahun 2003.Tentang Sistem Pendidikan Nasional.

Dessler, 2013, Manajemen Sumber Daya Manusia Human Reources, Jilid 2, Prenhalindo, Jakarta

Effendhi, Y. C. (2015). Analisis Rekrutmen Dan Motivasi Kerja Terhadap Kinerja Satpam Pt. Nojorono Kudus Dengan Kepuasan Kerja Sebagai Variabel Intervening (Doctoral Dissertation, Universitas Muria Kudus).

Fadil, M. (2017). Penerapan Manajemen Berbasis Madrasah (Mbm)(Studi Terhadap Karakteristik Input Mbm Di Min 4 Pringsewu) (Doctoral Dissertation, Uin Raden Intan Lampung).

Faisal, Sanapiah. 2010. Format-Format Penelitian Sosial. Jakarta: Pt. Raja Grafindo

Handoko, T. Hani. 2008. Manajemen Personalia dan Sumber Daya Manusia. BPFE. Yogyakarta.

Herman Sofyandi. 2013. Manajemen Sumber Daya Manusia. Graha Ilmu. Yogyakarta.

Indrawan, I. (2021). Manajemen Kelas. Penerbit Qiara Media. Kompetensi, Kinerja dan Produktivitas Kerja. PT Refika Aditama. Bandung

Marzuki, H. M. Saleh. 2012. Pendidikan Nonformal (Dimensi Dalam Keaksaraan Fungsional, Pelatihan, Dan Andragogi). Bandung : Pt. Remaja. 
Mustofa Kamil. 2010. Model Pendidikan dan Pelatihan; Konsep dan Aplikasi. Bandung: Alfabeta

Peraturan Kepala Kepolisian Negara Republik Indonesia Nomor 22 Tahun 2010 Tentang Susunan Organisasi Dan Tata Kerja Pada Tingkat Kepolisian Daerah.

Peraturan Kepala Kepolisian Negara Republik Indonesia Nomor 24 Tahun 2007 Tentang Sistem Manajemen Pengamanan Organisasi, Perusahaan Dan/Atau Instansi/Lembaga PemerintahPeraturan Kepala Kepolisian Negara Republik Indonesiano. Pol.: 18 Tahun 2006.

PP. No. 101 Tahun 2000 Tentang Pendidikan Dan Pelatihan Pegawai Negeri Sipil

Prabu Mangkunegara, A. A. Anwar. 2009. Manajemen Sumber Daya Manusia Perusahaan. Bandung: PT. Remaja Rosdakarya

Rachmawati, I. N. (2007). Pengumpulan data dalam penelitian kualitatif: wawancara. Jurnal Keperawatan Indonesia, 11(1), 3540.

Rosa, A.T.R., Irmawanti, Fitri., \& Trisnamansyah, Sutaryat. (2018). SMP Terbuka Sebagai Salah Satu Alternatif Dalam Meningkatkan Motivasi Belajar Masyarakat.Jurnal Fokus Manajemen Pendidikan

Sedarmayanti. 2017. Perencanaan dan Pengembangan SDM untuk Meningkatkan
Sugiyono. 2010. Metode Penelitian Pendidikan Pendekatan Kuantitatif, Kualitatif, Dan R\&D. Bandung: Alfabeta

Sugiyono.(1998). Metode Penelitian Administrasi Bandung: Alfabeta

Syahrudin, A., Majid, A., Yuliani, L., \& Qomariah, D. N. (2019). Penerapan Konsep Andragogi Oleh Tutor Kesetaraan Paket C Dalam Meningkatkan Motivasi Belajar Pada Warga Belajar. Jendela Pls, 4(1), 26-30.

Tommy Suprapto. PengantarTeori dan Manajemen Komunikasi. (Yogyakarta: Media Pressindo, 2000) hlm 122

Undang-Undang Republik Indonesia Nomor 2 Tahun 2002 Tentang Kepolisian Negara Republik Indonesia

Undang-Undang Republik Indonesia Nomor 5 Tahun 1997 Tentang Psikotropika, Ln. No. 10 Tahun 1997, Tln. No 96.

2009, Undang-Undang Nomor 22 Tahun 2009 Tentang Lalu Lintas Dan Angkutan Jalan, Departemen Perhubungan, Jakarta. Indonesia,

,Undang-undang Republik Indonesia Nomor 2 Tahun 2002 2002, TLN. NO 4168.

,Undang-Undang Republik Indonesia Nomor 2 Tahun 2002 Tentang Kepolisian Negara Republik Indonesia, Ln. No. 2 Tahun 2002, Tln. No 4168. 